\title{
APRESENTAÇÃO
}

\section{Ficções televisivas: deslocamentos e rupturas}

Em 1974, Raymond Williams lançava, em Television, questões intrigantes sobre um novo mundo, constituído por uma nova mídia, capaz de reunir som e imagem e de modificar repertórios culturais por onde estivesse. Dizia, à época, que "na maior parte do mundo, desde a propagação da televisão, houve um aumento de escala e intensidade da representação dramática sem precedentes na história da cultura humana"1.

Exatos vinte anos mais tarde, Rodowick reconheceu o surgimento de uma "cultura audiovisual"2 no cotidiano, afetada por corporações e padrões de consumo. Naquele momento, em que a evolução tecnológica já se anunciava de forma bastante ágil, elencou questões sobre relações de consumo, representações e experiências que emergiam em um novo contexto, no qual vídeos digitais em publicações multimídia ou mesmo publicações eletrônicas na internet começavam a ser disponibilizadas ao público.

O encontro de uma cultura marcada pelo hábito do consumo televisivo com novos dispositivos e negócios digitais tem, desde então, espalhado o mercado em direção ao desenvolvimento de narrativas capazes de provocar deslocamentos e rupturas, tanto nos formatos industriais, quanto na experiência dos públicos, que compartilham o hábito de "ver TV" com o de baixar filmes, seriados, assistilos em streaming ou em qualquer outro ambiente que não seja necessariamente sua sala de estar. 
Ao mesmo tempo em que promovem a ascensão de produtos associados à estética realista, como séries documentais, documentários e narrativas baseadas em fatos reais, também reescrevem, ressignificam e deslocam produtos ficcionais dos mais tradicionais, a exemplo das telenovelas e seriados, hoje recriados por fãs em redes sociais ou resgatados e oferecidas a novos públicos em aplicativos de streaming. O mundo mudou e a TV também.

No Brasil, este ano, são 70 anos de televisão, um veículo que configura a memória e também a identidade do país. Da popularidade das telenovelas a todo o universo narrativo dos gêneros informativos e do entretenimento, há uma infinidade de questões prontas para serem tratadas em pesquisas acadêmicas dentro e fora do campo da Comunicação. Um dado recentemente divulgado e comentado pelo jornalista e crítico Ricardo Feltrin demonstra que cerca de 82 milhões de brasileiros têm a TV como única fonte de entretenimento midiático ${ }^{3}$. Isso significa, também, que questionamentos sobre o "fim da televisão" desconhecem os cenários de desigualdade em um Brasil no qual a TV aberta, gratuita, tem grande capacidade de penetração e construção de imaginários.

A proposta deste Dossiê é refletir sobre as narrativas ficcionais na televisão, desde séries e produtos especiais até telenovelas ou seriados, abordando discussões sobre seu deslocamentos e rupturas em função de novos dispositivos e da configuração de um outro contexto sociocultural, marcado por tecnologias recentes, disputas por reconhecimento, processos produtivos difusos e audiências fragmentadas. O universo ficcional foi escolhido como temática por seu potencial como entretenimento e lazer, mas também de informação e educação, a partir de narrativas que abordam aspectos contemporâneos.

Essas características surgem problematizadas de forma diversa nos dez textos deste Dossiê, que abre com o texto "Crítica contemporânea da telenovela brasileira", assinado por Mariana Lima Pinheiro e Maria Immacolata V. Lopes. No artigo, as autoras analisam a crítica de telenovela realizada e veiculada no 
ambiente digital entre 2012 a 2018, a partir do estudo dos críticos Maurício Stycer e Cristina Padiglione. Além dos textos de crítica, oferecem trechos de entrevistas que orientam um modo de se fazer e entender a crítica especializada no país. Em outra reflexão, os pesquisadores Nilda Jacks, Guilherme Libardi, Joselaine Caroline e Vanessa Scalei trazem, no texto "Telenovela e memória: Vale a pena ver de novo?, reprises em tempo de pandemia", um conjunto de dados elucidativos sobre um fenômeno bastante atual: o hábito de se consumir narrativas originalmente exibidas no passado. No artigo, observam novos sentidos inaugurados pela audiência a partir das narrativas revisitadas.

As narrativas de ficção também são investigadas por Gabriela Borges e Daiana Sigiliano no texto "Malhação - Viva a diferença: ampliação e ressignificação do shipp Limantha no Twitter". Em uma extensa coleta de dados, elas buscam no universo de fãs e de suas postagens no microblog como a audiência se relaciona com nuances narrativas da telenovela. O texto traz, ainda, discussões sobre a literacia midiática presente nos conteúdos partilhados nesta rede social. Uma outra temporada de Malhação é objeto da investigação empreendida por Yvana Fechine, Cecília Almeida R. Lima, Diego Gouveia Moreira, Gêsa Cavalcanti e Marcela Chacel em "Merchandising social transmídia na Rede Globo: uma análise da temática LGBTQIA+ em Malhação". No estudo, o grupo reflete sobre o conjunto de ações socioeducativas apresentados a partir de um casal homoafetivo, analisando a estratégia transmídia utilizada pela Rede Globo para levantar questões sobre sexualidade.

Em "A construção de mundos na ficção televisiva e a questão do realismo: o caso de The Wire", Maria Carmem Jacob de Souza e João Eduardo Araújo discutem uma obra que parece apagar a distinção entre o mundo da ficção e o mundo vivido. O texto articula este movimento a trechos da biografia do autor-criador da série, David Simon, autor também de livros reportagens. Essa especificidade gera um universo narrativo singular no seriado, além da criação de uma forte ilusão de realidade.

A homofobia familiar, a homofobia clínica, a homofobia religiosa, a homofobia institucionalmente persecutória e a homofobia interiorizada são apresentadas no texto 
"Queer as a Zombie: metaforizações da homofobia na ficção televisiva", assinado por Anderson Lopes. O autor utiliza o conceito de metaforização discursiva para analisar a série britânica In the flesh e como o gênero e a sexualidade nas relações afetivas de personagens zumbis e gays surgem na trama. O exercício de análise de séries também é empreendido por Ligia Lemos, no texto "Complexidade narrativa na série Homens?: estudo baseado em técnicas de decupagem e categorização". A autora apresenta uma exploração metodológica de técnicas de análise de ficções televisivas complexas. Ao investigar os níveis discursivo e narrativo, apresenta a decupagem das cenas de um produto apontado como fruto de um deslocamentos em relação às abordagens presentes no gênero comédia no Brasil.

Partindo para o estudo de um aplicativo, os pesquisadores Paulo Eduardo Cajazeira e José Jullian Gomes Souza evocam, no texto "O arquivamento da memória televisiva em plataformas de aplicativos digitais", aspectos relacionados a formas de arquivamento da memória audiovisual. Na descrição da plataforma Globoplay, vislumbram um cenário em transformação, num ecossistema em construção da ecologia midiática audiovisual. Trata-se de um dispositivo que enseja novas formas de consumo e de relação com a audiência. Já Regiane Regina Ribeiro e Valquiria John, em texto intitulado "Estar no lugar de alguém: um processo de negociação entre espectador e personagem a partir da experiencialidade", apresentam a hipótese de que a centralidade do enredo na ficção seriada seria enfraquecido em nome do processo de negociação pela audiência.

O dossiê encerra com o artigo da pesquisadora Cristina Mungioli, autora de "Temporalidade e cronotopo na minissérie televisiva Se eu fechar os olhos agora". A análise da construção da temporalidade no primeiro episódio do produto, veiculado pela Rede Globo, leva a pesquisadora a refletir sobre o uso de flashbacks e flashforwards como procedimentos narrativos e estilísticos nos quais personagens e motivações se configuram e se reconfiguram ao longo da trama.

Tanto o estudo de obras, quanto de processos ou mesmo de novas ferramentas disponibilizadas ao consumidor de TV compõem esse Dossiê de modo a ampliar ainda mais os caminhos dos estudos da ficção em mídias populares massivas. Se a tecnologia 
tem provocado tantas revoluções no mundo, era de se esperar que seu encontro a uma mídia com 70 anos de história produzisse um universo desafiador, pronto a ser desbravado sob os mais variados pontos de vista. Espera-se, com essas reflexões, contribuir para a defesa da televisão como parte de um cotidiano - tal qual exposto por Arlindo Machado em homenagem que também compõe essa edição -, mas um cotidiano mutável, aberto a deslocamentos e rupturas.

Amanda Souza de Miranda Rosana de Lima Soares dezembro de 2020 